\title{
Mind the gaps: Professional perspectives of technology-based teaching and learning in the Foundation Phase
}

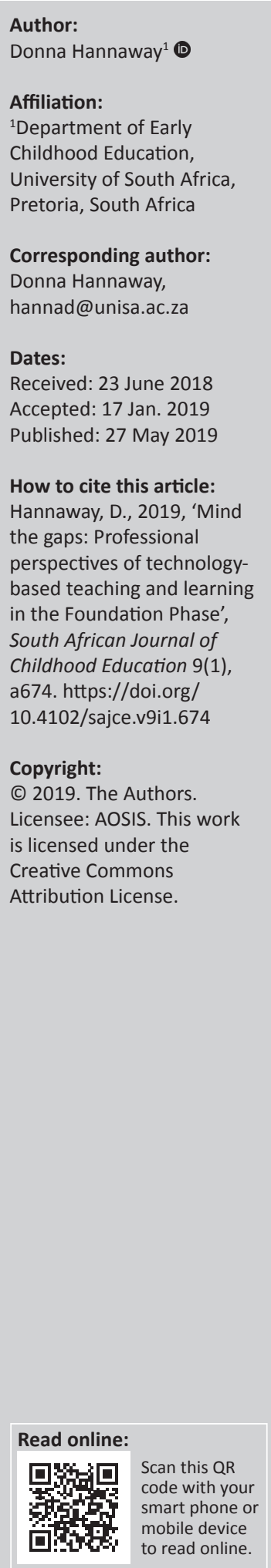

Background: As technology today is pervasive, this study seeks to examine how technological changes influence Foundation Phase learners, specifically the impact of technology on teaching and learning.

Aim: This study establishes professional perspectives of technology-based teaching and learning (TBTL) in the Foundation Phase from the vantage point of two district officials from the Gauteng Department of Education.

Setting: This study was set in a chosen district in the Gauteng province because the environment was identified as data rich, which implies that the participants were able to share information based on the large number of Foundation Phase schools that they service.

Methods: Qualitative case study methods such as interviews, opinion pieces and field notes from district officials servicing Foundation Phase schools were examined through the theoretical lens of the Technological Pedagogical and Content Knowledge model.

Results: The data gathered proved worthwhile in presenting the perspectives of TBTL in the Foundation Phase from one district in South Africa with regard to the benefits, barriers and gaps thereof.

Conclusion: Implications for technological infrastructure, a Foundation Phase TBTL policy framework, teacher preparation training and in-service training, and support in finding appropriate content were given.

Keywords: technology-based teaching and learning (TBTL); Foundation Phase Learners; district officials; Foundation Phase Teachers; Technological Pedagogical and Content Knowledge (TPACK).

\section{Introduction}

The pervasive technology of today is impacting the way in which people live their lives, their work and their social activities (Kruger 2014). Therefore, education in South Africa has to continually evolve to meet the goals and requirements of the Department of Education, and the specific learning outcomes in this century. Unlike previous generations, today's youth have all sorts of knowledge available at their fingertips as a result of ubiquitous technology. Because of this global technology boom, young children are now born into a 'wired' or 'connected' world comprising of the Internet, social media (such as Facebook and Twitter), instant messaging (such as WhatsApp) and digital equipment which is always available (Codrington \& Grant-Marshall 2011:86).

Therefore, it is of paramount importance to examine the effect of these technological innovations on learning, specifically how technological changes influence teaching and learning. The topic of technology-based teaching and learning (TBTL) in the Foundation Phase was explored through a qualitative study to identify the status thereof, as well as to highlight professional perspectives of TBTL. This study presents a bird's eye view of TBTL in the Foundation Phase from the perspective of two Gauteng district officials.

\section{Benefits and barriers of technology-based teaching and learning}

One of the main objectives of this study is to better understand TBTL and how it can support both teaching and learning. The importance of embracing TBTL in the Foundation Phase with the view to achieve educational aims is the rationale for this study. 
According to the World Bank (1998), technology can increase knowledge gain, and for developing countries it can provide optimal conditions for furthering the world of education, policy and business. The many advantages of using technology in schools have been extensively studied (Bialobrzeska \& Cohen 2005; Isaacs 2007; Laurillard et al. 2009; Mdlongwa 2012; National Council for Curriculum and Assessment [NCCA] 2004a; Tinio 2003). Tinio (2003) suggests that 'these tools have been touted as potentially powerful enabling tools for educational change and reform'. The E-Learning Africa Report (2012:47) posits that this is similar in Africa in that stakeholders 'hold high expectations about the ability of new technologies to scaffold progressive change at both institutional and system-wide levels'. According to Laurillard et al. (2009:290), incorporating digital technological innovations in education can transform pedagogy. Advantages of digital innovation include an increase in learner motivation, achievement of results, growth in higher order thinking and problem-solving, as well as learning to function in a collaborative manner (NCCA 2004a).

The E-Learning Africa Report (2012) and Mdlongwa (2011) both discuss the benefits of TBTL if it is implemented correctly. The use of technological innovation in schools increases motivation, enhances collaborative efforts and allows students to be connected to the global world of information. Additionally, the use of technology means that learners are co-collaborators in the production of knowledge, further serving to boost their self-esteem, and teaching them to be independent and responsible. Mdlongwa (2011) makes the point that there is increasing use of TBTL for administrative duties such as record-keeping and routine tasks, as well as facilitating communication between educators and students. According to Mdlongwa (2011), there are specific benefits when embracing TBTL; exposing learners to technology means such learners gain an advantage as the entire world of work depends on technology. Furthermore, learners can create their own knowledge and, as a result, 'cultivate a culture of personal information management, independent learning and working without supervision, communication skills, teamwork and study skills, which are highly valued in today's global workforce' (Mdlongwa 2012). In addition, if technology is integrated in the educational system, it leads to better teaching as technology helps the teacher to efficiently manage and administer his or her tasks and duties, and it also furthers communication (Bialobrzeska \& Cohen 2005).

The Department of Basic Education's (DBE 2015) Action Plan to 2019 details the priorities discussed in the National Development Plan 2030 (2012) with the aim of ensuring and maintaining a high quality of schooling in South Africa. The priority goals (five of the 27 goals) in the Action Plan deal with Grade R, teacher development, learning materials, school management and support for district offices. It is clear that these priority goals can be better achieved with technological innovation. This applies specifically to Goal 16, dealing with teacher development, where it is stated, 'improve ... computer literacy of teachers throughout their entire careers' (DBE 2015:1).
All the goals of the Action Plan to 2019 can be supported and achieved by integrating technology in schools. The benefits of TBTL in the Foundation Phase in South Africa are well known (as mentioned above) and thus the challenges in embracing technology must not be overlooked. As the DBE (2015) highlights:

[M]any have pointed to weaknesses in the system when it comes to the adoption of new technologies to improve the administration of the schooling system and the teaching and learning process. This is an inherently difficult area, not just in South Africa. Yet we need to do better if we are to avoid a widening of the gap between South Africa and other countries, even other middle income countries. (p. 15)

This statement clearly points to a digital divide in the education system in South Africa regarding TBTL. The literature examined for this study clearly points out the benefits of implementing technology in schools so that learners can acquire the necessary coping skills and knowledge for this demanding 21st century. However, the point is not only to acquire necessary skills; it is paramount to use TBTL to mitigate this digital divide. As the NCCA (2004b) states, the digital divide clearly shows the disparity in acquiring necessary skills and knowledge between those learners who are able to access technology and those who cannot. Kalaš (2010:118) defines digital divide as the lacuna in the skills necessary to be a digital citizen and the physical means to access such technological resources. The digital divide comprises two distinct categories: one where there are unequal opportunities to access and use various types of technology and one where there are differences in the outcomes of direct or indirect use of technology (Selwyn 2004:351).

Ranie (2013), Director of the Pew Study Center's Internet Project, in his international study on the digital divide points out how variables such as age, household income, community type and educational attainment affect whether people can use technology or not. In addition, the digital divide is affected by the support of parents and the surrounding community using TBTL (NCCA 2004a); less than optimal literacy, numeracy and problem-solving skills (OECD 2001); and disparities in the use of technology in school and outside of the school.

Prensky (2001) states that:

it is now clear that as a result of this ubiquitous environment and the sheer volume of their interaction with it, today's students think and process information fundamentally differently from their predecessors. (p. 1)

Teachers currently involved with Foundation Phase learners have probably come from an era very different from that of their learners. Prensky (2005) deems those learners born into the era of digital technology 'digital natives', and older adults (such as parents or teachers) as 'digital immigrants'. The 'digital immigrants' can create barriers to the 'digital native's' progression by clinging to a world view predating this technology age. 
It must be noted, however, that the terms 'digital native' and 'digital immigrant' have been criticised, and Prensky (2013) has responded to the false claim that everyone born before a certain age is ignorant when it comes to technology:

The Digital Natives/Digital Immigrants metaphor is NOT about what people know, or can do, with technology. Everyone has to learn in one way or another. It's more about culture and attitudes. (p. 1)

This statement points to the fact that a generation gap could be present, which would then make TBTL less than successful if the two generations do not learn from each other.

Laurillard et al. (2009:290) make it clear that any altering or remodelling of an education system must happen from within and cannot be done from the outside. Although technology in the form of computers, tablets and Internet connections is being implemented in many schools internationally, the curriculum and the skills of the teachers have not kept pace. While the benefits of using TBTL have been clearly articulated, the synergy between the benefits and the practice of education has not taken place (Conole et al. 2006).

In his comparative study in South Africa on information and communication technology (ICT) and enhanced learning, Mdlongwa (2011) discusses the challenges presented to both teachers and learners when attempting to integrate TBTL. Mdlongwa's (2012:4) findings are that learners' desire technology but language skills are now 'corrupted' by texting and social media; resources are lacking, especially with regard to Internet access; a shortage of teachers qualified in the use of technology exists; and there is restricted access to the necessary technology. In the South African educational arena, there is a further problem using TBTL, that is, the language barrier. Although English is used for $80 \%$ of computer software and the Internet (Tinio 2003), the majority of teachers and learners in South Africa use English only as their second language.

One of the key questions surrounding the challenges of ubiquitous technology therefore is 'who has access to what forms of technology and when and how it is used?' (Walker, Huddlestone \& Pullen 2010:10). According to Ndlovu and Lawrence (2012:2), the PanAf Study Agenda (2008-2011) reveals the finding that the South African ICT policy is not being effectively implemented, specifically in cases where economic and social prejudice is the root cause of the digital divide. Negating this, the Department of Communications (2013) advocates that their approach towards ICT is being reviewed in a manner that does not intentionally entrench the digital divide; access to technology, infrastructure and quality communication should not be the exception but rather the right of all.

\section{Theoretical framework}

Recently, a conceptual framework in educational study has emerged: the technological pedagogical and content knowledge (TPACK) (see Figure 1). This model has been

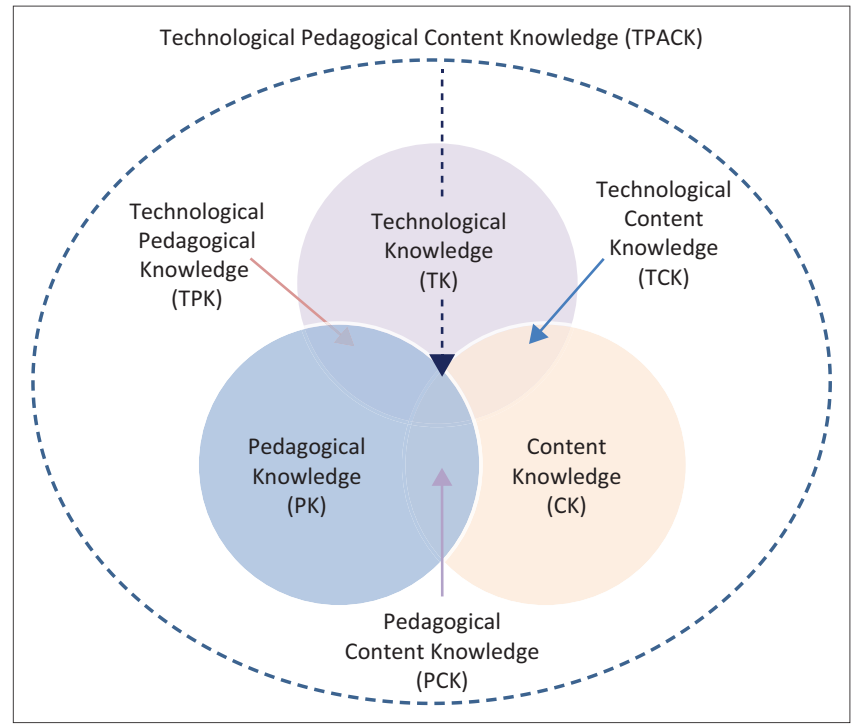

Source: Adapted from and with permission of the publisher, (C) 2012 by tpack.org FIGURE 1: Conceptualisation of technological pedagogical and content knowledge framework.

developed based on the perspective that, for a long time, technology in education has sought to reveal its theoretical foundations (McDougall \& Jones 2006; Roblyer 2005; Roblyer \& Knezek 2003). Various accounts for the battle to situate the study of education with theory deal with the increasing rate of technology change (Roblyer \& Knezek 2003), the lack of substantiated methodological designs and the over-reliance of practical, rather than theoretical, issues (McDougall \& Jones 2006; Roblyer 2005).

In 1986, Shulman posited the idea of pedagogical content knowledge (PCK) going further than mere knowledge of subject matter and including knowledge about how the content could be delivered. Within the technology environment, Koehler and Mishra (2005) developed Shulman's (1986) views of PCK to showcase the notion of TPACK). The conceptual framework 'recognizes the unique and interactive roles that content, technology, and pedagogy play in authentic teaching and learning environments' (Baran, Chuang \& Thompson 2011:370). For the purpose of this study, the TPACK framework was applied because of its potential in providing a foundation for study in TBTL, as well as providing theoretical guidance on the approach to TBTL according to district officials' views on the use of technology in the Foundation Phase. As Nyambane and Nzuki (2014) state, TBTL success is affected by various interconnected factors, and not by the presence (or lack thereof) of a single factor.

The TPACK's conceptual framework involves the synergy between three basic building blocks of knowledge technology, pedagogy and content - and intersects with the fundamental assumption of the application of suitable teaching content with suitable pedagogical methods and technology (Koehler \& Mishra 2008; Mishra \& Koehler 2006). The seven components of the TPACK conceptual framework devolve from adding technology to include elements of 
Shulman's (1986) original PCK. An outline of the components of the framework is shown in Figure 1.

- Technological knowledge (TK): Technological knowledge includes knowledge of the various technologies from low-tech pencil and paper to the interactive whiteboards, and digital technology such as the Internet and software.

- Content knowledge (CK): Content knowledge means subject matter knowledge (Mishra \& Koehler 2006). The content that teachers deliver, specifically how the knowledge is germane to its own content area, must be well understood by the teacher, such as Grade 1 Life Skills.

- Pedagogical knowledge (PK): This pertains to all the strategies and techniques of teaching, as well as knowledge of lesson planning, assessment, teaching methods, learner learning and classroom management.

- Pedagogical content knowledge (PCK): Pedagogical content knowledge infers content knowledge dealing with the process of teaching (Shulman 1986). As Howell (2012) explains, it is the way, or method, in which a subject can be made comprehensible to learners. Pedagogical content knowledge differs for individual content areas as it is a mixture of content and pedagogy with the aim of better developing teaching practices in the various areas of content.

- Technological content knowledge (TCK): Technological content knowledge means how a specific area of content can be better presented using technology (Schmidt et al. 2009). This implies that teachers have to realise that the use of technology changes the way learners comprehend various concepts within a specific knowledge content area.

- Technological pedagogical knowledge (TPK): Technological pedagogical knowledge illustrates the application of various forms of technology which can be used in teaching, and also provides insight that the use of technology changes the manner in which teachers teach and learners learn.

- Technological pedagogical content knowledge (TPACK): Technological pedagogical content knowledge is allied to the knowledge that teachers need to have for technology and teaching to converge in any given knowledge content area. According to Schmidt et al. (2009:125), this particular level of knowledge means that teachers must have 'an intuitive understanding of the complex interplay between the three basic components of knowledge (CK, PK, TK) by teaching content using appropriate pedagogical methods and technologies'.

This framework is pertinent to the study as it organises the understanding of the ways in which we teach (i.e. the pedagogy) and the ways in which learners learn (i.e. content) with what we teach (i.e. technology).

\section{Study methodology Study design}

I chose to use a qualitative case study as it explains the sequence of interpersonal events from the participants' accounts of technology in the Foundation Phase while discovering the key aspects of TBTL. This case study concentrated on the unit of analysis, namely, TBTL, and the case was bound in one district in the South African Foundation Phase context. Moreover, the case study was deliberately chosen 'to cover contextual conditions - believing that they might be highly pertinent to the phenomenon of study' (Yin 2003:13). The primary study site was a convenience sample of a chosen district in the Gauteng province because the environment was identified as data rich, which implies that the participants were able to share information based on the large number of Foundation Phase schools that they service.

\section{Ethical considerations}

As Flick (2009:36) notes, one can confront ethical issues at each stage of the study process and it is of paramount importance to apply various ethical measures to avoid maleficence to the participants. In this study, informed consent was obtained, the anonymity of participants was protected and confidentiality of information was provided. In addition, I ensured that no deception took place and all ethical guidelines were adhered to in the study (Laerd 2011). Ethical approval was obtained from the Ethics Committee at the institution of study, which involved a rigorous process of ethical scrutiny. The issues of informed consent, anonymity, confidentiality, deception and privacy were covered in the application for ethical clearance.

\section{Data collection techniques}

Qualitative study methods employ a naturalistic approach, seeking to understand phenomena in context-specific settings, such as the district officials in South African schools. This is an example of an existing context where the researcher does not have control over the phenomenon of interest (Patton 2002:39). I used qualitative data methods to collate and populate the data. Primary data were collected through semi-structured interviews, opinion pieces and field notes. An opinion piece might not be considered a qualitative data source of information, but it can reflect the participant's views and experiences of TBTL from their unique experience of being involved with the Foundation Phase. My personal observations, based on my study questions, were notated as field notes which I compiled during the semi-structured interviews.

\section{Sample and study site}

The study sample comprised two participants, both from a district in the Gauteng Department of Education. This district was chosen because these specialists in education were able to supply valuable information as they service a substantial number of Foundation Phase classes. They therefore could detail their experiences as well as provide the official view regarding TBTL in the Foundation Phase. These two district officials (participants D1 and D2) were able to provide the necessary data needed to investigate and explore the technological arena of the Foundation Phase. Table 1 presents some background information of the participants. 
TABLE 1: Background information of participants.

\begin{tabular}{lllll}
\hline Participant & Biological data & Qualification & Number of schools serviced \\
\hline D1 & 44 years, female & Bachelor of Education (honours) & 26 primary schools & Number of school visits \\
D2 & 47 years, female & Bachelor of Education (honours) & 28 primary schools & Six visits per school per term $\dagger$ \\
\hline
\end{tabular}

$\dagger$, Not all schools are visited in each term.

\section{Background information of the case}

The data collection commenced initially with four participants from one of the districts in the Department of Education, but in the end only two participants replied. The two district officials (participants D1 and D2) provided the data to investigate and describe the technological arena and TBTL in one district in the Gauteng province. The data collection process comprised a semi-structured interview with two district officials, who had extensive knowledge and experience of all types of schools in the South African Foundation Phase, that is, township schools, rural schools, inner city schools and independent schools.

Participant D1 is a 44-year-old female Foundation Phase senior education specialist, with a Diploma of Education (pre-primary), a higher Diploma of Education and a Bachelor of Education (honours) in Education Management. Her experience includes 4 years as a preschool teacher, and for the past 16 years she has been an education specialist in the Department of Education. The district where she works comprises 132 primary schools in the Foundation Phase, of which 26 fall in her area of responsibility. Participant D2 is a 47-year-old female Foundation Phase senior education specialist, with a Pre-Junior Higher Education Diploma, a Bachelor of Arts degree and a Bachelor of Education (honours) in Inclusive Education. This participant has some 24 years of experience in education, commencing as a Foundation Phase teacher, then as an Early Childhood Development/ Foundation Phase head of department. At present she works for the Department of Education. In her district, there are 28 public primary schools, including one farm school, five inner city schools (also known as ex-model C) and 22 township schools.

South African schools are 'organised and categorised in a rather complex and overlapping manner' (Department of Education 2009). Data taken from field notes implied that school categories are based on their geographical location, socio-economic status and, lastly, performance. Firstly, the term 'township' refers to the areas where people of the same race, especially black people, were moved away from city centres by the apartheid government and clustered together according to their ethnic groups. Township schools are located in these areas. Secondly, 'rural school' refers to those schools on the periphery of cities and townships that are governed by the state. Rural provinces mainly tend to have proportionally more schools with fewer learners compared to more urbanised provinces that tend to have proportionally fewer schools with more learners (DBE 2015).Thirdly, inner city schools, also called former model C schools, are urban schools that are located in the cities and that are privileged with resources and funding from the state. Lastly, the independent schools are private schools, although registered with the Department of Education; they do not receive state support. Private schools serve more affluent communities and are well-resourced, well-managed and staffed with wellqualified educators. This is in stark contrast to the other categories of schools mentioned above.

The questions posed in the semi-structured interview were designed to investigate the participants' perceptions of current teachers' technological, content and pedagogical knowledge derived from the TPACK framework. Other questions pertained to the technological arena in general, and how technology is currently employed for teaching and learning in different types of schools. The two district officials were also requested to write down their views - these are the opinion pieces. The opinion piece questionnaire was based on the prompts: 'who has access to what forms of technology and when and how is it used' and 'based on the pros and cons of the educational landscape with regard to TBTL, what recommendations can be made?' to further understand their perspective of Foundation Phase teachers' and learners' experiences of TBTL. The next section comprises the data analysis from the interviews, participants' opinion pieces and my field notes (where applicable). This section is structured in line with the key themes that emerged from the data.

\section{Data analysis}

Schwandt (2007:7) states that the data analysis component of the study should be rigorous, disciplined and organised. When interpreting a case study, Rule and John (2011:75) note that data analysis allows the researcher to generate generous descriptions, establish themes, produce explanations, as well as attempt to create theory. According to Creswell (2012), there are six steps generally used in the analysis of qualitative data, which in this study comprised the analysis of the data gleaned from the semi-structured interviews and the opinion pieces provided by the district officials, as well as my field notes. The six steps are outlined below:

- The data were first managed and organised (Creswell 2007:156), and then grouped by type, viz., interviews, opinion pieces and field notes. Subsequently, audio recordings from the two interviews were transcribed and formed part of the data collation.

- The data were then categorised or classified. In this step, the data were reorganised after a further reading, and notes were made to capture my first impressions. Then the data were divided into topic categories so as to further provide meaning to the raw data (Creswell 2007, 2012).

- Here various codes, as well as descriptions and subcategories, were formulated for the data. Creswell (2012:236) asks the following question: 'What in the responses of the participants' provide answers to my study questions?', which guided this step of the analysis. 
- As concrete findings emerged, they were devolved into in-depth descriptions of the data (Creswell 2007). In other words, the categorised responses from the participants regarding their descriptions and understanding of technology for teaching and learning were categorised according to the emerging themes.

- This step followed data interpretation (Creswell 2007). I carefully examined the findings and cross-referenced them with the literature to elucidate meaning. This was done by summarising the themes and examining similarities and/or differences between the study findings and the extant literature.

- In the final step, I used certain strategies to confirm the veracity of the findings of the themed data. Data were triangulated to confirm the accuracy of the findings. The data were also sent back to the participants to ensure that the responses had been accurately recorded and the correct meaning inferred regarding using technology for teaching and learning in the Foundation Phase.

Multiple themes emerged from the descriptions and experiences of the participants, opinion pieces and field notes. The data were purposefully arranged into themes, namely, Technological landscape of TBTL in the Foundation Phase, TBTL in the different school categories, barriers to TBTL and TPACK in TBTL, which are discussed below.

\section{Results}

\section{Technological landscape of technology- based teaching and learning in the Foundation Phase}

Participant D1 explained that in her view technology comprises machines, laptops, computers, telephones, etc., which are designed to make life easier. Technology is well integrated into her everyday life and she notes that it 'assists you to get a job done faster and more effectively where ever you may be' (Participant D1, female, 44 years). She acknowledges the importance of TBTL in the Foundation Phase, adding that 'we encourage teachers to make use of ICT when they are teaching' (Participant D1, female, 44 years). However, as she states, technology is not always accessible, and in addition it is expensive and can be impersonal since 'you don't spend time with other people, because there are all kinds of machines you can use to do a job' (Participant D1, female, 44 years).

In the same manner, Participant D2 said using technology is 'practical; including digital products, technological processes, resources and electronics, as a tool for communication (teaching and learning)'. In contact daily with technology, she uses it for administrative tasks, communication and as a teaching and learning tool. She further states that technology is an advantage as 'it leverages "lifelong" learning, caters for the current environment and it creates exciting, diverse leaning environments' (Participant D2, female, 47 years). However, Participant D2 noted that 'not all individuals are adequately empowered to use various digital/technological equipment (tech-savvy)', and that 'digital/technological equipment is being developed at such a fast pace that much of it quickly becomes obsolete'. In addition, issues of safety and cost are disadvantages of TBTL. This information from the participants formed the starting point of the interviews conducted with Participants D1 and D2.

Technology-based teaching and learning is not pervasive in the Foundation Phase in South Africa, and thus I needed to elicit the participants' opinions as to whether or not technology should be used in this phase. Both participants confirmed, however, that TBTL is important in this phase. The reasons they gave include the fact that technology can be used to support the curriculum if it is used as a study tool. Furthermore, the inclusion of technology in the Foundation Phase can assist teachers with planning and preparation for this generation of screen children (PD2), but it is noted, however, that this does not always happen.

\section{The use of technology-based teaching and learning in the various school categories within the Foundation Phase}

Both participants noted that the use of TBTL is not widely practised in the Foundation Phase of township, rural and inner city school categories in their respective districts. However, because of independent schools having more financial resources, they have much more TBTL. In addition, some schools have various technological tools but they are often not employed in teaching or learning, or they are misused. It is encouraging to note, however, that a number of schools are setting a good example by gradually incorporating technology using resources from external funding drives. These few schools are models to show how TBTL can be employed, although many more such schools are needed.

Using these model schools as examples, I endeavoured to initiate a response from the participants when they answered questions pertaining to various elements of the theoretical framework. I asked questions to understand the depth of technological, pedagogical and content knowledge in the Foundation Phase. Regarding the availability of technology, it was clear that there are many support services in the open education domain, yet only some schools have computers and very few have tablets. Participant D2 mentioned that most schools, other than the independent schools, do not have access to the physical technology needed to embrace these support services:

'So some of the resources are there. You see, but that's why it's important for the schools to have the tools you know ... the physical technological tools to supplement them.' (Participant D2, female, 47 years)

Regarding township schools, Participant D2 provided an illustration of how the space, classroom and surrounding 
environment can be arranged to support TBTL, with technology being provided by the school governing body:

'They've got good security measures in place where they've got tablets; look, the principal motivated the teachers to purchase their own tablets and she had something going with the company that was providing it for them to do study in terms of their planning. And then the learners also have this where they bring technology into the classroom during their computer lessons. That is one of the very few schools ...' (Participant D2, female, 47 years).

The participants stated that the majority of township schools do not have any technology devices but have a support centre for the teachers to access various technological resources. From the above example it is clear that technology in the township schools is very rare and mostly only for a specific lesson or short-term teacher study. It has not been incorporated into everyday teaching and learning. In addition, the participants also stated that this is also the situation with rural schools.

However, the inner city schools have better access to physical technology devices as these are independently supplied. It is to be noted that TBTL only takes places in either a single computer period or on an ad hoc occasion. Some model inner city schools have embraced the importance of TBTL, and there are efforts to integrate technology into the curriculum. Participant D1 stated the following:

'But what's currently happening now is that many of the schools, because they see the value of ICT, are starting to now purchase more and more tablets and you know, the monitors and everything, and they're starting to use, to plan in terms of CAPS ${ }^{1}$ you know, the implementation and alignment to the curriculum and they look at how can they then you know, bring in ICT in their planning.' (Participant D1, female, 44 years)

\section{Challenges regarding integrating technology-based teaching and learning into the Foundation Phase}

The barriers to integrating TBTL into the Foundation Phase were noted by the participants, which included the high cost of purchasing equipment, and the financial constraints pertaining to training teachers in technology and maintaining the continued use of technology. Participant D1 noted the following in her opinion piece:

'Using iPads or laptops or the Internet comes with planning. It cannot be a separate plan, but should become part and parcel of the curriculum that's being taught. Many teachers are not skilled enough to be able to know how to use ICT and this makes the financial burden even heavier on a school, because it's of no use having the equipment, but teachers are unable to use it. For this reason, teachers are then obliged to attend training on how to use ICT and the $\mathrm{SGB}^{2}$ ends up paying for this as well. This, I think, is also one of the main reasons why schools do not invest in purchasing equipment.' (Participant D1, female, 44 years)

1.National Curriculum Statements of South Africa.

2.School Governing Body.
It is clear that one of the major reasons that TBTL is not more readily embraced is the teacher. It is the attitude of the teacher that determines the success of the introduction of technology when it is available:

'Again, it's about teacher attitude ... And the willingness to want to use technology in the classroom.' (Participant D2, female, 47 years)

'From school visits it is evident that a large percentage of the teachers in the Foundation Phase are very 'senior' in years. Thus, there is a sense of 'fear' and 'inability' or lack of knowledge in using computers and programmes to assist with teaching and learning.' (Particpant D1, female, 44 years)

Further barriers to TBTL include lack of government support and financial resources required to obtain and implement technology on a sustained basis. During the interviews, and as reiterated in their opinion pieces, the participants stated that there are few examples of best practice, and where these exist, it is only because of funds obtained externally. Participant D1's opinion piece substantiates the state of TBTL currently:

'The use of ICT in schools is encouraged, but cannot be forced as the financial burden rests mainly on the parents. The department have not been able to provide schools with computers or iPads or even the human resource to be able to teach learners.' (Participant D1, female, 44 years)

Participant D2 concurs with Participant 1, stating that teachers, learners and district officials must have the requisite technology tools if TBTL is to be successful. Both participants concur that government resources are few and the sustainability of these resources is a problem. Specifically, they both make the point that often the first initial structures are not problematic, but maintaining support for them is a huge barrier to the success of TBTL;

'It's more the system is in place, or they're working on the system but now from there you, to be able to make use of the system you need to have the resource you know. You have to have the training, you need to have a laptop, you need to be able to know how to use it, which is a way that the department is trying to assist teachers in terms of their workload and planning and that kind of thing but it is just that it's taking very long you know.' (Participant D2, female, 47 years)

Further hindrances to TBTL comprise, inter alia, the workforce and the less than optimal distribution of both training and resources:

'Yes. So there needs to be manpower. With the manpower must come equipment and training. And budget obviously.' (Participant D2, female, 47 years)

In addition, because of high crime rates and pervasive theft, the participants stated that expensive technology equipment in the school is vulnerable.

\section{Technological pedagogical and content knowledge in technology-based teaching and learning in the Foundation Phase}

Although there are many barriers to TBTL, the participants noted that some schools have technology tools and show 
exemplary practice in TBTL. However, such schools are few and far between. The chalkboard is still used pervasively in most schools. When the participants detailed their personal experiences regarding the use of technology in the Foundation Phase, they highlighted that although TBTL is not pervasive in schools, it is possible to integrate it. Participant D2 explained that technology generally is used to supplement teaching in inner city, township and rural schools. The following quote, from Participant D2, pertains to an inner city school:

'... presentations with the learners. If you go to computer classes, they learn to draw on the art program and they do the maths, they do some reading.' (Participant D2, female, 47 years)

'They do some language, Afrikaans ...' (Participant D1, female, 44 years)

If and when technology is available, it seems that township and rural schools use it as an additional subject, rather than it being integrated into normal teaching. Thus, limited examples are found in all the school categories where technology is an enabler of pedagogy. The problem is that this state of affairs does not further the aims of integrating technology into teaching and learning. According to the participants, the focus is placed on the actual technology tools and the skills necessary to use them, rather than embracing technological content knowledge or technological pedagogical knowledge.

'Admitting, learners in both township and former Model C schools do have access to computer lessons, weekly. They are taught basic computer literacy such as learning the naming of the parts of the hardware and working on the MS Word and 'Paint'. What is a shortfall is that there is no real integration with any of the subjects that the teacher is currently teaching in her classroom.' (Participant D2, female, 47 years)

However, it must be noted that there is more teaching with regard to technology in schools in the inner city than in township and rural schools. In inner city schools, the management actively campaigns for the use of technology. Generally, technology is used by the teachers for their lesson planning, and in all too few occasions it is used to motivate their teaching. Participant D1 states the following:

'You can't just go and say 'we're going to ...' You must have it ready. And that is where their teaching is informed by technology. The ICT informs what they're going to teach the learners. So it's like a link.' (Participant D1, female, 44 years)

Participant D2 stated that ideally either a technology advocate in the school or the school management needs to support TBTL so that it can be implemented and maintained, but sadly this is not normally the case. The participants agreed that the lack of technological pedagogical knowledge is because of two main reasons: the nature of the Foundation Phase teaching, and the curriculum and the assessment of the curriculum being highly prescriptive. The participants were asked if technology changes the manner in which teachers are teaching, and unfortunately this is not the case. As Participant D2 explains, teachers want to teach young children correctly, and the department workbook comprises the major resource for ensuring teaching and learning take place. Technological content knowledge remains unamended because of the prescriptive nature of the curriculum. It is evident that neither teachers nor learners (in all the school categories) use technology to develop new and unique content. It is interesting to note, however, that publishers are printing content which deals with technology in the curriculum.

\section{The future of technology-based teaching and learning in the Foundation Phase}

Because of the evident lack of TBTL in the Foundation Phase, the participants were requested to provide their views on how teachers and learners can benefit from technology in the South African Foundation Phase. These recommendations include altering the teachers' perspective on TBTL, ensuring resources are available for teacher preparation and engendering collaboration between stakeholders. It is clear that the attitudes of the teachers must be changed to embrace technology, and the necessary training in how to use technology for teaching must be provided. Any policy regarding the use of technology for teaching must be easily comprehensible. Furthermore, the participants expounded on the need for government to supply resources, as well as other stakeholders such as the department, parents and higher education institutions, to effect a technology collaboration.

Participant D1, in her opinion piece, summarised her view on the use of technology, strongly advocating that the relevant departments in the Department of Education need to form a collaborative initiative:

'The use of technology is incorporated in workshops that we present to teachers - we use technology to communicate and cascade information to teachers and schools. However, I must be candid in assuming that not all colleagues are 'au fait' with technology. The purpose is to motivate study of subject matter, cater for interactive teaching and learning and to empower teachers. Perhaps this needs to be a point of departure in identifying the gap in use of technology in curriculum delivery? Perhaps at District level, we should stop working in silos implying that the Curriculum Unit and the E-learning unit should work together closely.' (Participant D1, female, 44 years)

The participants were asked to provide input on how learners can learn and how teachers can teach successfully if technology is embraced:

'Yes, that's where we have to come in now because it's all fair and well you know how to use a tablet, you know how to click a mouse but you now bring that into teaching successfully. Not just for the sake of using it you know, not just because I have a computer to put the screen up and say look, here is my computer, but ... To actually know exactly how are they going to integrate this? And to reinforce what you're teaching and how our children are learning with the technological tools that you have.' (Participant D2, female, 47 years)

\section{Discussion and implications}

In summary, the experiences of schools in TBTL that use minimal or no technology are completely different from the 
TBTL experience of teachers and learners in technology-rich schools. Moreover, the fractured nature of TBTL in the Foundation Phase was highlighted. The data analysis provided evidence of digital resources in the Foundation Phase. To what extent they are used and how they are used to achieve desirable educational outcomes still need to be further interrogated. The strengths and weaknesses of TBTL were reviewed in the literature and came to the fore in empirical study so that a comprehensive overview could be achieved before looking at the situation of TBTL in South Africa. Regarding the barriers or limitations to TBTL, the findings concur with extant literature noting the fact that people learn, live and function with technology (Kruger 2014) which is not the case in the South African school system. This is also the case regarding the potential of TBTL as the findings show that policy and practice are varied and fragmented, and the majority of teaching and learning in the South African Foundation Phase still takes place in the old traditional manner. Furthermore, delineating the parameters of TPACK, which involves the interrelation between technological and pedagogical content knowledge, is unsuitable with findings in the literature, as there is little or no TBTL taking place in the majority of schools.

Little to no TBTL is taking place because of the 'generational gap' between teachers and learners; disparities between the 'haves' and the 'have nots' in access to technology; no integration between technological, pedagogical and content knowledge; and a lack of communication between the stakeholders who deal with teaching and learning in the Foundation Phase. The most serious lacuna is the digital divide, with only a privileged few having access to technology, while the majority do not have the necessary financial resources. The generational gap, that is, differences in age between teacher and learners, severely compromises TBTL. Minimal or no technology is present in the Foundation Phase; therefore, it cannot be aligned with technological, pedagogical and content knowledge in the theoretical framework. In the few cases where there is technology in certain schools, it forms a discord with either teaching or learning. Discipline disparity has resulted from a lack of training opportunities in TBTL for teachers, learners and other relevant Foundation Phase stakeholders. Communication is also seen as a barrier because various educational departments, institutions and individuals work in their respective silos for TBTL initiatives and do not collaborate in the sharing and exchanging of technology knowledge and ideas.

In this study, the arena of technology and the official viewpoint regarding TBTL in the Foundation Phase were investigated and the findings strongly revealed massive disparities between schools where TBTL is implemented and those where it is not implemented. As a result of the findings, the following recommendations are made to ensure successful TBTL in the Foundation Phase in the future:

- Firstly, government should ensure a technology infrastructure in the Foundation Phase.
- Secondly, the Department of Education should formulate a specific policy framework for TBTL in the Foundation Phase.

- Thirdly, teachers should be taught the necessary skills to enable them to learn about, use and embrace technology.

- Fourthly, Foundation Phase teachers need to incorporate technology into their teaching and learning preparation programmes so that they can change the way they teach and implement TBTL. In addition, the professional development of teachers must be attended to in this technological 21st century to upgrade their skills.

- Lastly, Foundation Phase learners need to be given access to the most appropriate content, and this content must be formed and supported by technology.

\section{Conclusion}

The significance of this study is that it prepares the way for an educational study perspective of teaching and learning in the Foundation Phase that is based on technology. Today's learners are socialised in a manner completely different from that of the previous generation in that we all now live in a 'wired' and connected global information society. In the beginning of the information era, the impact of technology was mainly concerned with the access to information or how it was disseminated, but now the pervasive use of technology should be extended to embrace the manner in which teachers teach (i.e. the pedagogy) and the manner in which learners learn. Knowledge content must be integrated with technology.

\section{Acknowledgements Competing interests}

The author declares that she has no financial or personal relationships that may have inappropriately influenced her in writing this article.

\section{Authors' contributions}

D.H. is the primary researcher and author of the manuscript.

\section{Funding information}

There were no sources of support in terms of grants, equipment, drugs and/or other support that facilitated the conduct of the work described in the article or the writing of the article itself.

\section{References}

Baran, E., Chuang, H. \& Thompson, A., 2011, 'TPACK: An emerging study and development tool for teacher educators', The Turkish Online Journal of Educational Technology 10(4), 370-377.

Bialobrzeska, M. \& Cohen, S., 2005, Managing ICT's in South African schools: A guide for school principals, SAIDE, viewed 08 August 2014, from https://www.unterricht. educa.ch/de/literaturliste.

Codrington, G. \& Grant-Marshall, S., 2011, Mind the gap: own your past, know your generation, choose your future, Penguin Books, Johannesburg.

Conole, G., White, S., Oliver, M. \& Conole, G., 2006, 'The impact of e-learning on organisational roles and structures', in G. Conole, M. Oliver \& G. Conole (eds.), Contemporary perspectives in e-learning study: Themes, methods and impact on practice, pp. 69-81, Routledge, Abingdon.

Creswell, J.W., 2007, Qualitative inquiry and study design: Choosing among five approaches, 2 nd edn., SAGE, Thousand Oaks, CA. 
Creswell, J.W., 2012, Educational research: planning, conducting and evaluating quantitative and qualitative research, 4th edn., Pearson Education, Boston, MA.

Department of Basic Education, 2015, Action plan to 2019 towards the realisation of schooling 2030 taking forward South Africa's National Development Plan 2030, Department of Education, Pretoria.

Department of Communication, 2013, National integrated ICT policy green paper Government Gazette, 24 January 2014, Pretoria.

Department of Education, 2009, South Africa Schools Act 84 of 1996. The nationa minimum uniform norms and standards for school, Government Printers, Pretoria.

E-Learning Africa Report, 2012, The e-learning Africa report 2012, viewed 08 August 2014, from http://www.elearning-africa.com/report2012.

Educational Testing Services (ETS), 2002, A framework for ICT literacy: Digita transformation: A report of the international ICT literacy panel, Centre for Global Assessment, Princeton, NJ.

Flick, U., 2009, An introduction to qualitative study, SAGE, London.

Howell, J., 2012, Teaching with ICT: Digital pedagogies for collaboration and creativity, Oxford University Press, Victoria, Australia.

Isaacs, S., 2007, ICT in education in South Africa, Survey of ICT and education in Africa, 2 (53), Country Reports, infoDev/World Bank, Washington, DC.

Kalaš, I., 2010, Recognizing the potential of ICT in early childhood education Analytical survey. UNESCO Institute for Information Technologies in Education, Moscow, Russian Federation.

Koehler, M. \& Mishra, P., 2005, 'What happens when teachers design educational technology? The development of technological pedagogical content knowledge' Journal of Educational Computing Research 32(2), 131-152.

Koehler, M.J. \& Mishra, P., 2008, 'Introducing TPCK', in AACTE Committee on Innovation and Technology (ed.). The handbook of technological pedagogical content knowledge (TPCK) for educators, pp. 3-29, Lawrence Erlbaum Associates, Mahwah, NJ.

Kruger, M., 2014, 'Global trends for mobile learning: Focus on learning in higher education', in Proceedings of the 2nd Annual Technology for Teaching and Learning Forum, held in Johannesburg, 19-20 March 2014.

Laerd, 2011, Principles of study ethics, viewed 28 February 2012, from http:// dissertation.laerd.com/articles/principles-of-study-ethics.php.

Laurillard, D., Oliver, M., Wasson, B. \& Hoppe, U., 2009, 'Implementing technologyenhanced learning', in N. Balacheff, S. Ludvigsen, T. de Jong, A. Lazonder \& S. Barnes (eds.), Technology-enhanced learning: Principles and products, pp. 289-306, Springer, Dordrect.

McDougall, A. \& Jones, A., 2006, 'Theory and history, questions and methodology: Current and future issues in study into ICT in education' Technology, Pedagogy and Education 15(3), 353-360. https://doi.org/ 10.1080/14759390600923915

Mdlongwa, T., 2011, 'ICT and enhanced learning at Pearson High School', Unpublished master's dissertation, Nelson Mandela Metropolitan University, Port Elizabeth.

Mdlongwa, T., 2012, 'Information and communication technology (ICT) as a means of enhancing education in schools in South Africa: Challenges, benefits and recommendations', Policy Brief: Africa Institute of South Africa, Briefing No 80 August 2012.

Mishra, P. \& Koehler, M.J., 2006, 'Technological pedagogical content knowledge: A framework for teacher knowledge', Teachers College Record 108, 1017-1054. https://doi.org/10.1111/j.1467-9620.2006.00684.x

National Council for Curriculum and Assessment (NCCA), 2004a, Curriculum assessment and ICT in the Irish context: A discussion paper, viewed 02 July 2014, from http://www.ncca.ie/uploadedfiles/ECPE/Curriculum\%20Assessment andICT.pdf.
National Council for Curriculum and Assessment (NCCA), 2004b, Curriculum assessment and ICT in the Irish context: A discussion paper, viewed 02 July 2014 from https://www.ncca.ie/media/1787/curriculum_assessment_and_ict_in_the_ from https://www.ncca.ie/media/1787/cu

National Development Plan 2030, 2012, Our future-Make it work. Executive Summary, April 2012, National Planning Commission, Republic of South Africa, Pretoria.

Ndlovu, N.S. \& Lawrence, D., 2012, 'The quality of ICT use in South African classrooms', in Conference Proceedings, Strategies to overcome poverty and inequality: 'Towards Carnegie III', Cape Town, 3-7 September 2012, University of Cape Town, pp. 1-27.

Nyambane, C.O. \& Nzuki, D., 2014, 'Factors influencing ICT integration in teaching A literature review', International Journal of Education Study 2(3), 1-18.

Organisation for Economic Cooperation and Development (OECD), 2001, Learning to change: ICT in schools, OECD Publications, Paris.

Patton, M.Q., 2002, Qualitative evaluation and study methods, 3rd edn., SAGE, Thousand Oaks, CA.

Prensky, M., 2001, 'Digital natives, digital immigrants, Part II: Do they really think differently?', On the Horizon 9(6). https://doi.org/10.1108/10748120110424843

Prensky, M., 2005, 'Shaping tech for the classroom: 21st-century schools need 21st century technology', viewed 10 April 2014, from http://www.edutopia.org/adoptand-adaptshapingtech-for-classroom.

Prensky, M., 2013, 'Digital natives', [Blog] Marc Prensky Practical and Visionary viewed 20 December 2016, from http://marcprensky.com/?s=digital+natives\&x= $0 \& y=0$.

Ranie, L, 2013, 'The state of digital divides', Pew Study Internet Project, viewed 09 June 2014, from http://www.pewinternet.org/2013/11/05/the-state-ofdigital-divides-video-slides/.

Roblyer, M.D., 2005, 'Educational technology study that makes a difference: Series introduction', Contemporary Issues in Technology and Teacher Education 5(2), 192-201.

Roblyer, M.D. \& Knezek, G.A., 2003, 'New millennium study for educational technology: A call for a national study agenda', Journal of Study on Technology in Education 36(1), 60-71.

Rule, P. \& John, V., 2011, Your guide to case study research, Van Schaik Publishers, Pretoria.

Schmidt, D.A., Baran, E., Thompson, A.E., Mishra, P., Koehler, M.J. \& Shin, T.S., 2009 'Technological Pedagogical Content Knowledge (TPACK): The development and validation of an assessment instrument for preservice teachers', Journal of Study on Technology in Education 42(2), 123-149. https://doi.org/10.1080/15391523.2 009.10782544

Schwandt, T.A., 2007, The Sage dictionary of qualitative inquiry, 3rd edn., SAGE, Thousand Oaks, CA.

Selwyn, P., 2004, 'Reconsidering political and popular understandings of the digital divide', New Media \& Society 6(3), 341-362. https://doi.org/10.1177/1461444 804042519

Shulman, L., 1986, 'Paradigms and study programs in the study of teaching: A contemporary perspective', in M.C. Wittrock (ed), Handbook of study on teaching, pp. 3-36, MacMillan, New York.

Tinio, V., 2003, ICT in education, ICT for Development, United Nations Development Programme, New York.

Walker, A., Huddlestone, B. \& Pullen, D.L., 2010, 'An overview of technology in society: An introduction to technoliteracy', in D. Pullen, C. Gitsaki \& M. Baguley (eds.) Technoliteracy, discourse and social practice: Frameworks and applications in the digital age, pp. 1-19, IGI Global, New York.

World Bank, 1998, The world communication and information report. Quoted in C. Blurton. New directions of ICT-use in education, UNESCO, Hong Kong.

Yin, R.K., 2003, Case study research: Design and methods, 3rd edn., SAGE, Thousand Oaks, CA. 